\title{
Stock market development and economic growth: Evidence from India, Pakistan, China, Malaysia and Singapore
}

\author{
Muhammad Aamir Ali ${ }^{1}$, Nazish Aamir ${ }^{2}$ \\ ${ }^{1}$ School of Commerce and Accountancy, University of Management and Technology, Lahore, Pakistan \\ ${ }^{2}$ School of Commerce, University of Central Punjab, Lahore, Pakistan \\ Email address: \\ aamir.ali@umt.edu.pk (M. A. Ali), paradiso.aamir@gmail.com(Aamir. N) \\ To cite this article: \\ Muhammad Aamir Ali, Nazish Aamir. Stock Market Development and Economic Growth: Evidence from India, Pakistan, China, \\ Malaysia and Singapore. International Journal of Economics, Finance and Management Sciences. Vol. 2, No. 3, 2014 , pp. $220-226$. \\ doi: $10.11648 /$ j.ijefm.20140203.13
}

\begin{abstract}
Stock market is the only source through which we can come to know about the volume of interest showed by investors by buying and selling the shares of listed companies. This paper is written to empirically show the GLS regression analysis based on panel data (1991-2011) that unto how significantly economic growth is influenced by stock markets. The econometric models are made by considering GDP per capita as dependent variable and stock markets' variables, FDI, Investments, EXP and GDS as explanatory variables. The models are made to study by taking stock market size and liquidity separately and then collectively. Results show that GDP per capita is significantly explained by independent variables.
\end{abstract}

Keywords: GDP Per Capita, FDI, Investments, EXP and GDS

\section{Introduction}

To study the relationship between stock market development and economic growth has become a very hot issue of research. A lot of time series, cross-sectional and panel studies have been made by many authors such as Muhammad Enamul Haque and Nahid Fatima (2011) worked to empirically explore the relationship between stock market development and long-run per capita growth rate of Bangladesh using the two dynamic panel models for the sample period of 1980-2007. Their results' reflect that the nothing of the dynamic models is effective one to identify the stock market linkage to per capita growth rate in Bangladesh. Aktham Maghayereh (2003) studied the long run relationship between the Jordanian stock prices and selected macroeconomic variables by using Johansen's methodology in co-integration analysis and monthly time series data over for the period from January 1987 to December 2000. This study finds that macroeconomic variables-that is, exports, foreign reserves, interest rates, inflation, and industrial production are reflected in stock prices in the Jordanian capital market. On the other hand many valuable work is availabe is also available such as
Ake Boubakari and Dehuan Jin (2010) explored causality relationship between stock market and economic growth based on the time series data compiled from 5 Euronext countries (Belgium, France, Portugal, Netherlands and United Kingdom) for the period 1995:Q1 to 2008.

In this paper we studied a panel regression test on five emerging economies of Asia includes: India, Pakistan, China, Malaysia and Singapore from 1991-2011. No work has been done on these countries. No doubt that time series studies may be available on individually and many authors have considered some of these countries in their cross sectional studies as well as panel studies.

In this paper we test three hypotheses one is to test significant influences of explanatory variables such as FDI (foreign direct investments), Investments (Gross capital formation), EXP (Expenditures made by the governments \% to GDP), GDS (Gross domestic savings as \% to GDP), MCR (Market capitalization ratio) and STR (stock traded ratios) on dependent variable GDP per capita. Secondly to test significant influences of explanatory variables such as FDI (foreign direct investments), Investments (Gross capital formation), EXP (Expenditures made by the governments \% to GDP), GDS (Gross domestic savings as \% to GDP) and taking MCR (Market capitalization ratio) 
alone. Third is to significant influences of explanatory variables such as FDI (foreign direct investments), Investments (Gross capital formation), EXP (Expenditures made by the governments \% to GDP), GDS (Gross domestic savings as \% to GDP) and STR (stock traded ratios) on dependent variable GDP per capita.

Studies considereing the above three aspects have not been made, but last two tests were introduced and applied by Baboo M Nowbutsing (2009) but that was time series study based on the economy of Mauritius.

The results show that our alternate hypotheses are well supported by our panel regression tests. This paper proves a significant results of applied panel regression test by taking logarithm of all the variables because Baboo $\mathrm{M}$ Nowbutsing (2009) and Farzad Rahimzadeh (2012) also took natural logarithm of variables in their studies.

\section{Relevant Scholarships}

Farzad Rahimzadeh (2012) wrote that the growing importance of stock market around the world has reinforced the belief that finance is an important ingredient for growth. Their focus was mainly on stock market development and economic growth.

Ross Levine and Sara Zervos (1998) show that stock market liquidity and banking development both positively predict growth, capital accumulation, and productivity improvements when entered together in regressions, even after controlling for economic and political factors. Their results are consistent with the views that financial markets provide important services for growth.

Hamid Mohtadi and Sumit Agarwal examine the relationship between stock market development and economic growth for 21 emerging markets over 21 years, using a dynamic panel method. Results suggest a positive relationship between several indicators of the stock market performance and economic growth both directly, as well as indirectly by boosting private investment behavior.

Imran Ali, Kashif ur Rehman, Ayse Kucuk Yilmaz, Muhammad Aslam Khanand Hasan Afzal (2010) examined the causal relationship between macro-economic indicators and stock market prices in Pakistan. The data from June 1990 to December 2008 have been used to analyze the causal relationship between various macro-economic variables and stock exchange prices

Tarika Singh, Seema Mehta and M. S. Varsha (2011) attempted to examine for Taiwan the casual relationship between index returns and certain crucial macroeconomic variable namely employment rate, exchange rate, GDP, Inflation and money supply. Their analysis was based on stock portfolios rather than single stocks. In portfolio construction, four criteria are used: Market capitalization, price/earnings ratio (P/Eratio), $\mathrm{PBR}$ and yield. The purpose was to make a finer point with respect to the relationship between economic growth and stock market especially in terms of stock prices. Empirical findings revealed that exchange rate and GDP seem to affect returns of all portfolios, while inflation rate, exchange rate, and money supply were having negative relationship with returns for portfolios of big and medium companies.

Hsin-Hong Kang and LIU, PING-CHIN(2008) Investigate the relationship between financial development indicators and economic growth for the case of India and Taiwan over the period 1997-2005.

Thorsten Beck, Ross Levine(2004) investigates the impact of stock markets and banks on economic growth using a panel data set for the period 1976-1998 and applied recent generalized-method-of moments techniques' developed for dynamic panels. They found that stock markets and banks positively influence economic growth.

Farzad Rahimzadeh (2012) Stock market and banking sector has a key role in economic development in each country. Therefore in their paper, using data related to the Middle East and North Africa in the period 1990-2011, the role and importance of stock market and the banking sector on improving production have been studied with panel data

Aboudou Maman Tachiwou (2010) Stock market is an indicator of an economy financial health. That paper examines the impact of stock market development on growth in West African monetary union. A time series econometric investigation is conducted over the period 1995 - 2006.

Anson Wong (2011) argued that the empirical evidence suggests that the development of stock markets in China, USA, United Kingdom, Japan and Hong Kong have independently a strongly positive correlation with their economic growth.

Tichaona Zivengwa, Joseph Mashika, Fanwell K Bokosi and Tendai Makova (2011) explored the causal link between stock market development and economic growth in Zimbabwe using annual time series data for the period 1980 to 2008. The study evaluated the nature of the relationship between stock market development and economic growth in Zimbabwe. The stock market development was measured using two variables namely stock market size as measured by stock market capitalization as a ratio of GDP and stock market turnover as measured by the value of stocks traded as a ratio of stock market capitalisation.

\section{Hypothesis Statement}

Based on all above literatures and specially the study of Baboo M Nowbutsing (2009) we can state our hypothesis and models as follows:

\begin{tabular}{ll}
\hline Alternate Hypotheses & \\
\hline 1 & $\mathrm{H}_{\mathrm{A}}:$ The GDP per capita is significantly explained by FDI,GDS,EXP,INV,MCR\&STR \\
2 & $\mathrm{H}_{\mathrm{A}}:$ The GDP per capita is significantly explained by FDI,GDS,EXP,INV \& MCR \\
3 & $\mathrm{H}_{\mathrm{A}}:$ The GDP per capita is significantly explained by FDI,GDS,EXP,INV \& STR \\
\hline
\end{tabular}




\section{Methods}

\subsection{Models and Definitions of Variables}

\begin{tabular}{lcll}
\hline Model number & & & \\
\hline 1 & $Y_{\mathrm{t}}$ & $=$ & $\beta_{0}+\beta_{1} \mathrm{FDI}_{\mathrm{t}}+\beta_{2} \mathrm{GDS}_{\mathrm{t}}+\beta_{3} \mathrm{EXP}_{\mathrm{t}}+\beta_{4} \mathrm{INV}_{\mathrm{t}}+\beta_{5} \mathrm{MCR}_{\mathrm{t}}+\beta_{6} \mathrm{STR}_{\mathrm{t}}+\mathrm{e}_{\mathrm{t}}$ \\
2 & $\mathrm{Y}_{\mathrm{t}}$ & $=$ & $\beta_{0}+\beta_{1} \mathrm{FDI}_{\mathrm{t}}+\beta_{2} \mathrm{GDS}_{\mathrm{t}}+\beta_{3} \mathrm{EXP}_{\mathrm{t}}+\beta_{4} \mathrm{INV}_{\mathrm{t}}+\beta_{5} \mathrm{MCR}_{\mathrm{t}}+\mathrm{e}_{\mathrm{t}}$ \\
3 & $\mathrm{Y}_{\mathrm{t}}$ & $=$ & $\beta_{0}+\beta_{1} \mathrm{FDI}_{\mathrm{t}}+\beta_{2} \mathrm{GDS}_{\mathrm{t}}+\beta_{3} \mathrm{EXP}_{\mathrm{t}}+\beta_{4} \mathrm{INV}_{\mathrm{t}}+\beta_{5} \mathrm{STR}_{\mathrm{t}}+\mathrm{e}_{\mathrm{t}}$ \\
\hline
\end{tabular}

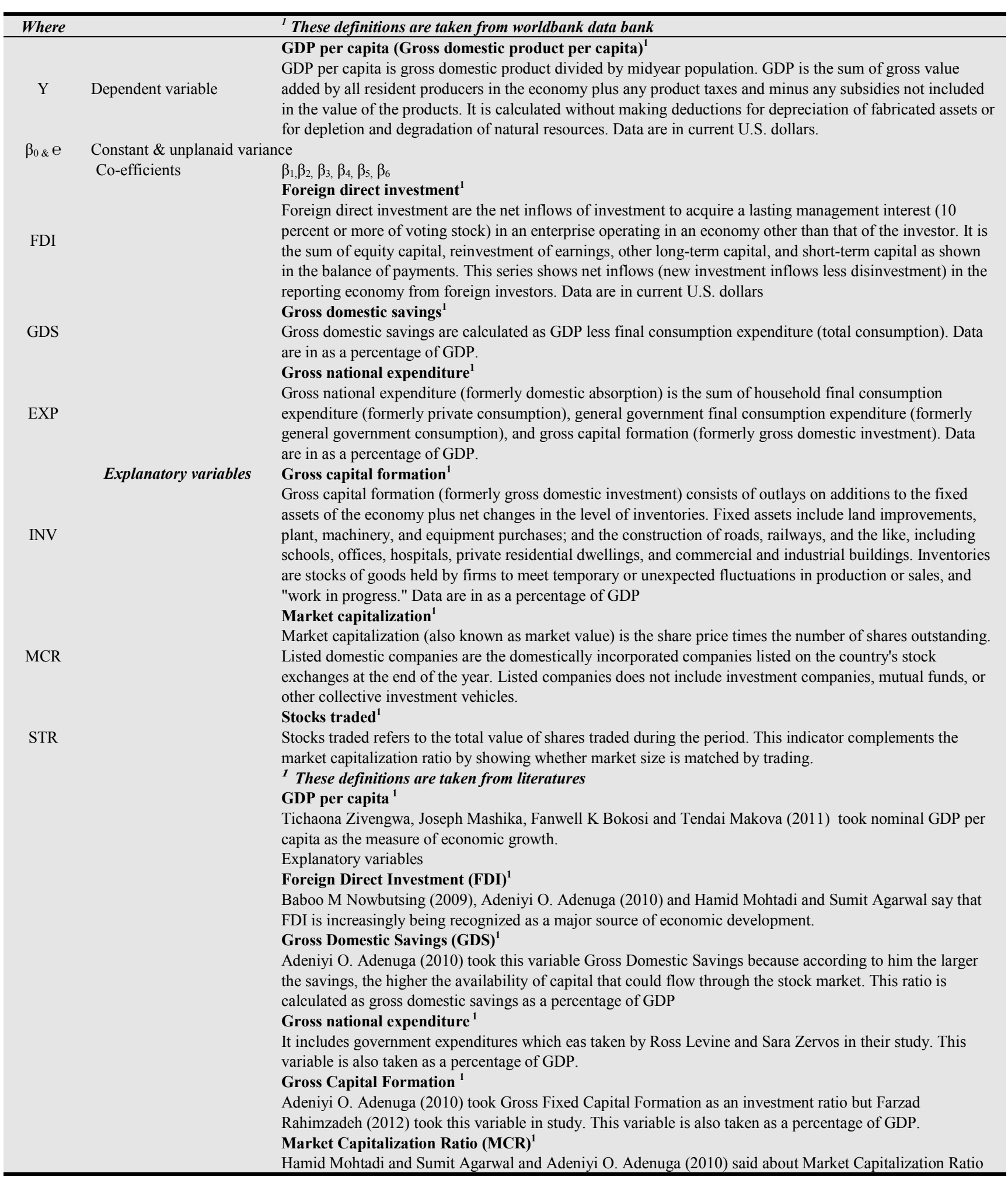




\begin{tabular}{ll}
\hline Where & ${ }^{I}$ These definitions are taken from worldbank data bank \\
\hline that This measure equals the value of listed shares divided by GDP. The assumption behind this measure is \\
that overall market size ispositively correlated with the ability to mobilize capital and diversify risk on \\
aneconomy-wide basis. \\
Total Value of Shares Traded Ratio (STR) ${ }^{1}$ \\
Hamid Mohtadi and Sumit Agarwal and Adeniyi O. Adenuga (2010) also says that this measure equals total \\
value of shares traded on the stock market exchange divided by GDP. The total value traded ratio measures \\
the organized trading of firm equity as a share of national output and therefore should positively reflect \\
liquidity on an economy-wide basis. The total value traded ratio complements the market capitalization ratio: \\
although a market may be large, there may be little trading.
\end{tabular}

\subsection{Econometric Model and Data Source}

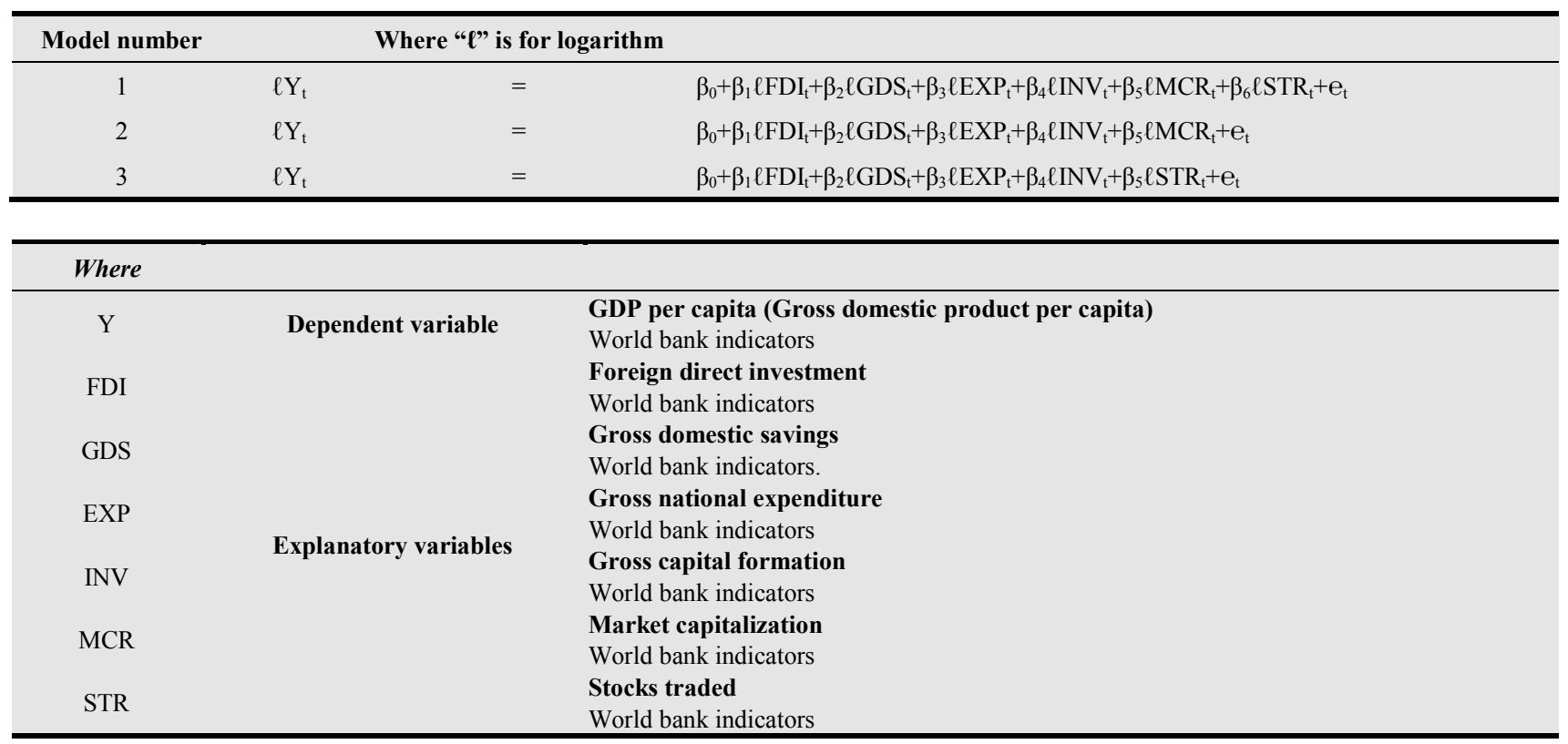

\section{Conclusion}

All results are based on panel Random-effects GLS regression shows significantly proving our hypotheses accept the Pvalue of STR in model three showing insignificance.

\section{Results}

Random-effects GLS regression Group variable: company

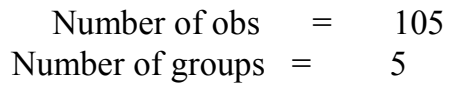

\begin{tabular}{lll}
\hline Model 1 & P values \\
\hline$\ell$ Y & Dependent variable & GDP per capita (Gross domestic product per capita) \\
$\ell$ FDI & & 0.000 \\
$\ell$ GDS & 0.000 \\
$\ell$ EXP & 0.000 \\
$\ell$ INV & Explanatory variables & 0.000 \\
$\ell$ MCR & & 0.000 \\
$\ell$ STR & & 0.020 \\
constant & 0.000 \\
\hline & \\
\hline Model 2 & & P values \\
$\ell$ Y & & GDP per capita (Gross domestic product per capita) \\
$\ell$ FDI & Dependent variable & 0.000 \\
$\ell$ GDS & & 0.000 \\
$\ell$ EXP & Explanatory variables & 0.000 \\
$\ell$ INV & & 0.000 \\
$\ell$ MCR & & 0.000 \\
\hline
\end{tabular}




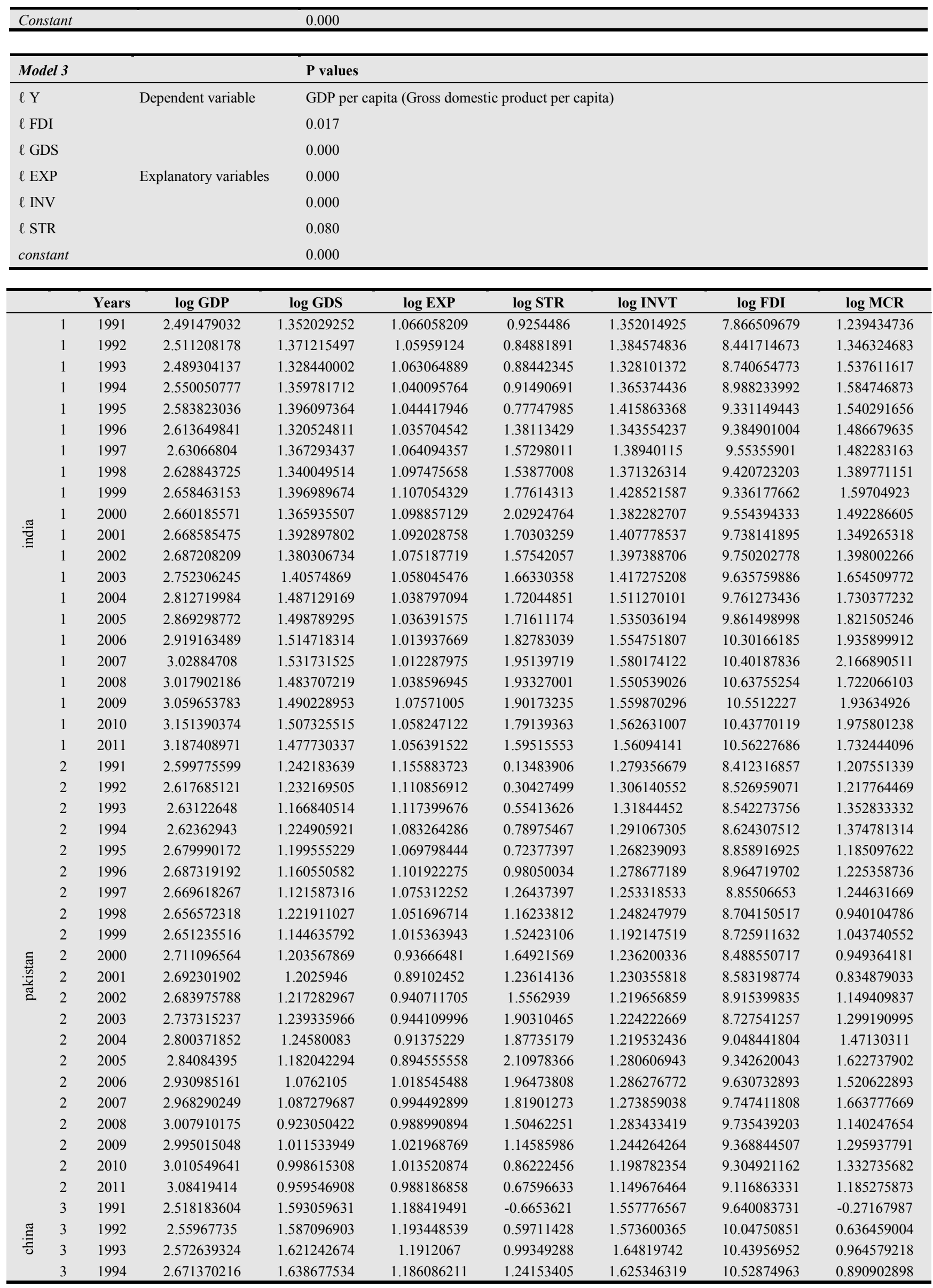




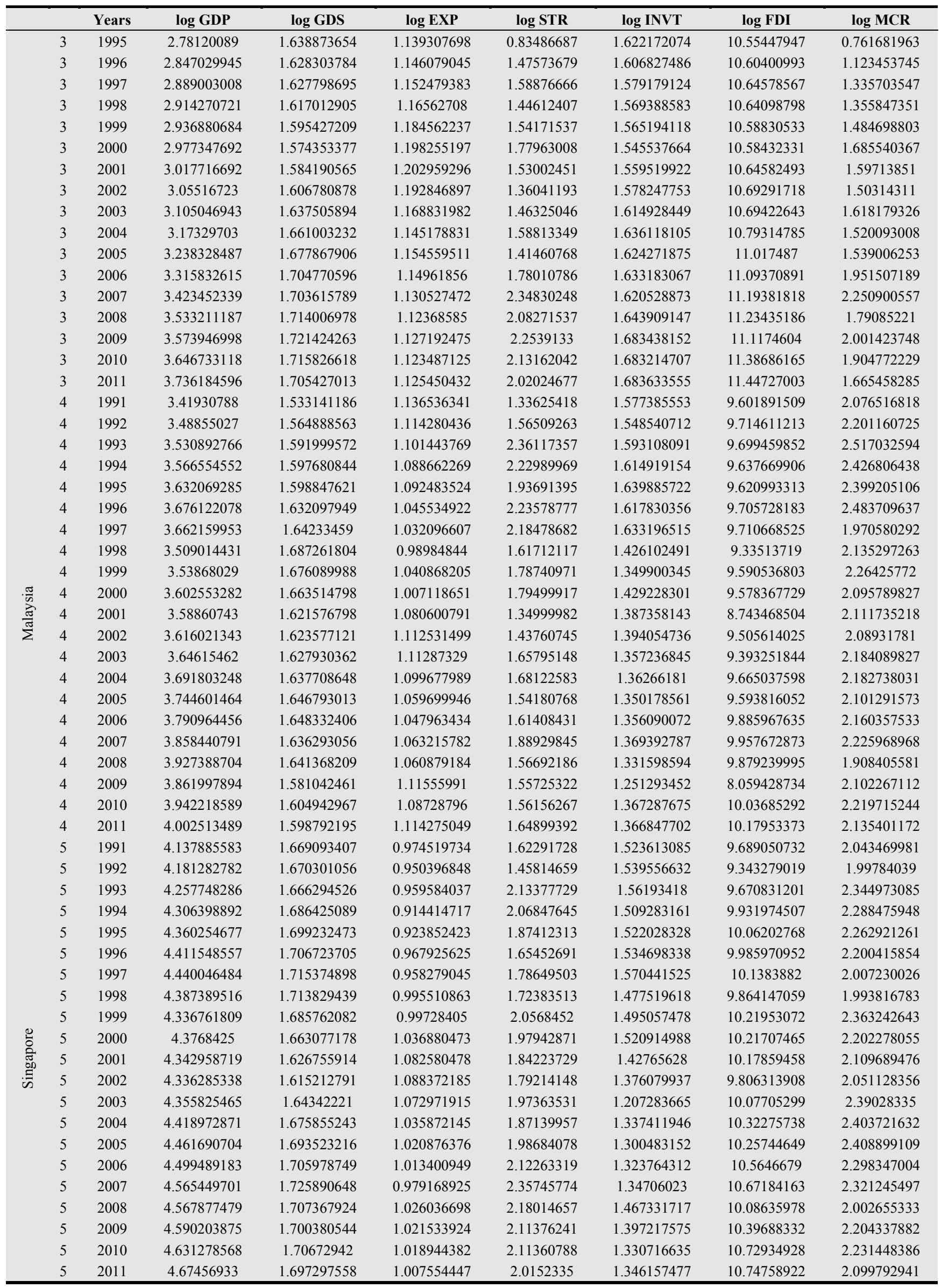




\section{References}

[1] Baboo M Nowbutsing, University of Mauritius, Reduit, Mauritius M. P. Odit, University of Technology, Mauritius (2009)," Stock Market Development And Economic Growth: The Case Of Mauritius". Volume 8, Number 2

[2] Muhammad Enamul Haque and Nahid Fatima (2011)," INFLUENCES OF STOCK MARKET ON REAL ECONOMY:A Case Study of Bangladesh" The Global Journal of Finance and Economics, Vol. 8, No. 1, (2011) : 49-60.

[3] AKTHAM MAGHAYEREH (2003)," Causal Relations among Stock Prices and Macroeconomic Variables in the Small, Open Economy of Jordan" JKAU: Econ. \& Adm., Vol. 17, No. 2, pp. 3-12 (1424 A.H./2003A.D.).

[4] Ross Levine; Sara Zervos (Jun., 1998)," Stock Markets, Banks, and Economic Growth" The American Economic Review, Vol. 88, No. 3. (Jun., 1998), pp. 537-558.

[5] Ake Boubakari and Dehuan Jin (2010)," The Role of Stock Market Development in Economic Growth: Evidence from Some Euronext Countries" International Journal of Financial Research Vol. 1, No. 1; December 201014 ISSN.

[6] Hamid Mohtadi and Sumit Agarwal," Stock Market Development and Economic Growth:Evidence from Developing Countries".

[7] Imran Ali, Kashif Ur Rehman, Ayse Kucuk Yilmaz, Muhammad Aslam Khanand Hasan Afzal (2010)," Causal relationship between macro-economic indicators and stock exchange prices in Pakistan" African Journal of Business Management Vol. 4 (3), pp. 312-319, March, 2010.
[8] Tarika Singh, Seema Mehta and M. S. Varsha(2011)," Macroeconomic factors and stock returns: Evidence

[9] from Taiwan" Journal of Economics and International Finance Vol. 2(4), pp.217-227, April 2011.

[10] Hsin-Hong Kang and LIU, PING-CHIN(2008)," Comparative Studies between Financial Development Indicators and Economic Growth Relevance in India and Taiwan" International Conference on Applied Economics ICOAE 2008

[11] Thorsten Beck, Ross Levine(2004)," Stock markets, banks, and growth:Panel evidence" Journal of Banking \& Finance 28 (2004) 423-442.

[12] Farzad Rahimzadeh (2012)," BANKING SECTOR, STOCK MARKET AND ECONOMIC GROWTH:EVIDENCE FROM MENA COUNTRIES" INTERNATIONAL JOURNAL OF SOCIAL SCIENCES AND HUMANITY STUDIES Vol 4, No 2, 2012 ISSN: 1309-8063

[13] Aboudou Maman Tachiwou (2010)," Stock Market Development and Economic Growth: The Case of West African Monetary Union" International Journal of Economics and Finance Vol. 2, No. 3; August 2010.

[14] Anson Wong (2011)," Development of Financial Market and Economic Growth: Review of Hong Kong, China, Japan, The United States and The United Kingdom" International Journal of Economics and Finance Vol. 3, No. 2; May 2011.

[15] Tichaona Zivengwa, Joseph Mashika, Fanwell K Bokosi and Tendai Makova (2011)," Stock Market Development and Economic Growth in Zimbabwe" International Journal of Economics and Finance Vol. 3, No. 5; October 2011. 